\title{
Perspectives of Plant Associated Microorganisms in Drought Management of Crops
}

\author{
M. Manjunath", S. K. Yadav, S. Desai and M. Maheswari \\ Division of Crop Sciences, ICAR-Central Research Institute for Dryland Agriculture, \\ Hyderabad-500 059, Telangana, India \\ *Corresponding author
}

\section{A B S T R A C T}

\section{Keywords}

Cereals, Drought, Legumes,

Microbiome,

Rainfed, Semi-arid

Article Info

Accepted:

10 October 2020

Available Online:

10 November 2020
Cereals and legumes are largely grown under harsh rainfed conditions in India, which is further complicated by climate change and climate variability. Tropical drylands are experiencing deficit rainfall over the years. Due to this, agricultural production is affected in arid and semi arid regions. There is an urgent need to find low cost, ecofriendly, sustainable solutions to manage crop productivity under rainfed situations to help resource poor small and marginal farmers in particular. Plant microbiome interactions offer plants to tide over adverse conditions viz., biotic and abiotic stresses through their various activities. The mechanisms they employ under moisture stress conditions include; synthesis and accumulation of biochemical compounds like proline and sugars, regulation of ethylene synthesis, production of phytohormones and exopolysaccharides, enhancement of root growth, regulation of gene expression etc. In addition to water deficit stress, drylands are also deficient in various plant nutrients. Consortia of microorganisms with multiple improved functions such as nitrogen fixation, drought tolerance, nutrient mobilization and solubilization have a potential to improve drought tolerance, plant growth and development under rainfed conditions.

\section{Introduction}

Water is the major limiting factor for crop production in arid and semi arid regions of the world (Daryanto et al., 2016; Maheswari et al., 2017). More than $50 \%$ of arable lands are going to be affected by severe drought by 2050, threatening crop production and food security due to the increased frequency of droughts over the years. The climate change will further aggravate the problem in the near future making farming very difficult (Lobell et al., 2011; Mancosu et al., 2015; Sallam et $a l ., 2019)$. Continuous drought over the years can cause severe water crisis, this would seriously affect agriculture dependent livelihoods and may even lead to food insecurity, famine and death (Karim et al., 2014; Reid 2011). It is predicted that, drought would severely affect the maize, soybean and cotton growing regions across the globe (Ngumbi and Kloepper, 2016). About 40\% deficit in water is causing 20-40\% reduction in yield of important crops such as wheat and maize (Daryanto et al., 2016). In the United States, drought stress has resulted in around 
$67 \%$ of crop losses in the past 50 years (Comas et al., 2013). Improving the agricultural productivity is of paramount importance to ensure food and nutritional security to ever increasing human population especially resource poor small and marginal farmers (Glick 2014; Naved et al., 2014a). Cereals and legumes are largely grown under rainfed conditions in arid, semi-arid and sub humid regions (Creswell and Martin 1998; Farooq et al., 2017).

Crop improvement through plant breeding and genetic engineering technologies help to develop crop plants tolerant to various biotic and abiotic stresses (Ngumbi and Kloepper, 2016; Reid 2011). However, conventional breeding methods are slow, labour intensive and sometimes lead to loss of useful traits. Genetic engineering although is faster but consumer acceptance level of genetically modified crops and their products varies across different countries (Ngumbi and Kloepper, 2016; Reid 2011). Under these circumstances, the pressing need of the hour is to find low cost, ecofriendly, sustainable solutions to manage the problem of water deficit stress without compromising the crop yield in rainfed agriculture (Chakraborty et al., 2013; Ngumbi and Kloepper, 2016; Ruzzi and Aroca, 2015).

Plant beneficial microorganisms have tremendous potential to increase the drought tolerance and productivity of plants (Chanway and Holl, 1994; de Souza et al., 2016: Kasim et al., 2016). They display wide array of plant growth promoting characteristics, which aid in regulating the physiological responses to water deficit and improved survival and growth of plants under water stress conditions (Morasco et al., 2012, 2013; Redman et al., 2011).

The Plant Microbiome comprises of plant and soil associated microorganisms (Rout 2014).
The performance of plants in a given environment is influenced by their microbiome. Microbiome helps plants to overcome various biotic and abiotic stresses (Panke-Buisse et al., 2015).

The plant associated microorganisms in rainfed crops are mainly grouped as;

Rhizospheric microorganisms: The microbes which are in close vicinity of roots and those which are positively affecting the plant growth and development are referred as plant growth promoting microorganisms (PGPMs) (Glick 2012; Kloepper and Schroth, 1978).

Endophytic microorganisms: Endophytic microorganisms are the one which found inside the tissues of plants without causing any harm (Naved et al., 2014b; Schulz and Boyle, 2006).

Epiphytic or phyllopsphere microorganisms: These are the microbes which are found on the above ground plant surfaces (Lindow and Brandl, 2003).

\section{Factors affecting crop productivity}

Several biotic (pest and diseases) and abiotic (drought, salinity, cold, heat, nutrient deficiency, heavy metals, etc.) factors affect the agricultural production worldwide (Pandey et al., 2017).

Amongst all, drought is the single most important factor causing severe yield losses in agriculture (Budak et al., 2015; Daryanto et al., 2016; Maheswari et al., 2017; Naveed et al., 2014; Stromberger et al., 2017).

In this communication, we discuss about the role of plant associated microorganisms in the management of drought stress in cereals and legumes of rainfed agriculture. 


\section{Roles of plant beneficial microorganisms}

The plant beneficial microorganisms help plant growth and development by several mechanisms (Backer et al., 2018; Hardoim et al., 2008; Vardharajula et al., 2011). These include nitrogen fixation (Mirza et al., 2001), solubilization and mobilization of phosphorus (Sridevi and Mallaiah, 2009), nutrient uptake (Mantelin and Touraine, 2004), phytohormone production (Naveed et al., 2014), root growth (Somers et al., 2004), alleviation of biotic (Compant et al., 2005; Hill et al., 1994) and abiotic stresses such as drought (Naveed et al., 2014; Cohen et al., 2009; Vilchez and Manzanera, 2011), salinity (Jha et al., 2011) and yield improvement (Hameeda et al., 2008).

\section{Mechanisms of drought management in rainfed cereals and legumes}

\section{Plant adaptations}

Plants being sessile organisms have developed certain mechanisms to cope up and survive under changing environmental conditions through various morphophysiological modifications and evolutionary adaptations (Chmielewska et al., 2016; Juenger, 2013).

\section{Drought escape}

Annual herbaceous plants complete their life cycle before the onset of drought, there by escape moisture stress conditions for growth and development (Kooyers, 2015).

\section{Drought avoidance}

Plants avoid ill effects of moisture stress by maintaining basic physiological functions and modifying a few or more morphological features like closure of stomata and increased synthesis and accumulation of wax on leaf surfaces (Blum, 2005; Fang and Xiang, 2015; Tardieu, 2013; Zhang et al., 2005)

\section{Drought tolerance}

Plants withstand moisture stress conditions without affecting its growth and development, there would be a minimum loss in yield (Luo, 2010). Osmotic adjustment and accumulation of solutes play a very important role in adaptation of crop plants to moisture stress through cellular functions and turgor maintenance (Blum, 2017; Ullah et al., 2017). The mechanisms include antioxidative stress metabolism and scavenging of reactive oxygen species. Plants accumulate various biochemical compounds such as sugars, amino acids, polyamines etc. to adapt to water stress conditions (Fang and Xiong, 2015).

Microorganisms help to enhance the drought tolerance of plants by various mechanisms;

\section{Synthesis and accumulation of biochemical compounds}

Plants resort to elevated synthesis of sugars, amino acids and polyamines during drought stress conditions. Proline is a very important amino acid, it help plants to tolerate stress by maintaining cell turgor or osmotic balance, preventing electrolyte leakage by stabilizing cell membrane, reducing the concentration of reactive oxygen species (Farooq et al., 2008; Hong et al., 2000; Kiani et al., 2007; Mansour 1998). Beneficial bacteria stimulate the synthesis of proline and sugars under stress conditions to prevent the damage to plants (Mafakheri et al., 2010; Sandhya et al., 2010; Silvente et al., 2012). The Bacillus spp. improved the growth and development of maize (Zea mays L.) plants under water stress conditions by accelerating the synthesis of sugars, proline, amino acids and by restricting the electrolyte leakage, and increased the dry biomass by $46.6 \%$ than uninoculated control 
(Kavamura et al., 2013; Vardharajula et al., 2011). Inoculation of greengram (Vigna radiata L.) seeds with Pseudomonas fluorescens Pf1 boost the tolerance of plants to drought stress conditions upto 8 days by enhancing the synthesis of proline (Saravanakumar et al., 2011). The Pseudomonas aeruginosa GGRJ21 enhances the tolerance level of mung bean (Vigna radiata $\mathrm{L}$.) to drought by increasing shoot and root length by producing proline (Sarma and Saikia, 2014). Treatment of wheat seeds with Pantoea alhagi- strain LTYR-11Z ${ }^{\mathrm{T}}$ augment the plant growth by increasing the synthesis of soluble sugars and reducing the chlorosis of wheat (Triticum aestivum L.) leaves under drought stress conditions (Chen et al., 2016). The Bacillus subtilis strain B26 enhanced the drought tolerance of plants by increasing the synthesis of total soluble sugars and starch whenever plants are under water stress (Gagne-Bourque et al., 2015). Certain bacteria like Bacillus megaterium BOFC15 produce polyamines like spermidine for enhancing the drought adaptiveness of plants through increased synthesis of ABA, antioxidant enzymes and improving root growth (Zhou et al., 2016).

\section{Regulation of ethylene synthesis}

Ethylene is an important plant growth regulating hormone. It influences all the developmental stages of plants, its levels are low during growth and development stages but maximum at ripening and senescence period (Glick, 2005). The ethylene production in plants is affected by several factors such as drought, high temperature, pest and disease incidence, heavy metal etc. and its synthesis in plants increases during stress conditions (Abeles et al., 1992). This increased level of ethylene synthesis lead to chlorosis, inhibition of shoot and root growth and early senescence of plants (Glick, 2005; Glick, 2014; Mayak et $a l ., 2004)$. The enzyme 1-aminocyclopropane 1-carboxylate (ACC) deaminase converts the ACC, the precursor of ethylene into ammonia and $\alpha$-ketobutyrate (Glick 2012; Honma and Shomomura, 1978). The ACC deaminase producing bacteria helps plants from drought and other environmental stress conditions by restricting the synthesis of ethylene under stress conditions (Gamalero and Glick, 2015). The Serratia marcesens (STJ5) and Pseudomonas thivervalensis (STF3) by their ACC deaminase activity improved the growth and development of maize (Zea mays L.) under field conditions (Shahzad et al., 2013). The ACC deaminase producing Serratia and Aerococcus enhanced the shoot length $(80.2 \%)$, root length $(54.6 \%)$ and shoot dry weight $(95.4 \%)$ of wheat (Triticum aestivum L.) seedlings under water stress conditions (Bangash et al., 2013). The consortium comprising of Ochrobactrum pseudogrignonense RJ12, Pseudomonas sp. RJ15 and Bacillus subtilis RJ46 improved the drought tolerance in Vigna mungo L. and Pisum sativum L. by decreasing ACC accumulation and down regulation of expression of ACC oxidase gene (Saikia et al., 2018). Application of ACC deaminase producing Bacillus amyloliquefaciens and 30 $\mathrm{Mg} \mathrm{ha}^{-1}$ biochar with two irrigations increases the straw yield $(75 \%)$ and grain yield $(77 \%)$ of wheat over the control with four irrigations (Zafar-ul-Hye et al., 2019).

\section{Synthesis of exopolysaccharides (EPS)}

Biofilm is formed by the complex group of bacteria by attaching to various biotic and abiotic surfaces (Batool and Hasnain, 2005). Beneficial bacteria produce exopolysaccharides (EPS), a diverse polymer of sugars which aid in attachment of bacteria to different surfaces and subsequently development of biofilm. Biofilm retains more water around them, due to this, they could survive under water stress and other environmental variations (Batool and 
Hasnain, 2005; Chenu and Roberson, 1996; Costerton et al., 1987; Qurashi and Sabri, 2012; Roberson and Firestone, 1992). The EPS enabled the attachment of microorganisms to root surface and helped plants tolerate drought conditions by improving soil moisture content, root length and plant biomass (Bashan and Holguin, 1997). Inoculation of maize (Zea mays L.) seeds with EPS producing Alcaligenes faecalis (AF3), Pseudomonas aeruginosa (Pa2) and Proteus penneri (Pp1) improved the relative water content, sugar and proline levels and helped the plant to tide over drought stress conditions (Naseem and Bano, 2014). The Rhizobium sp. strain YAS34 by its EPS production helps sunflower (Helianthus annus L.) plants to grow under drought stress conditions by improving soil aggregation and adhesion of soil particles around roots (Alami et al., 2000). The exopolysaccharide producing Pseudomonas putida improved the root growth and plant biomass of sunflower (Helianthus annus L.) seedlings under water stress conditions (Sandhya et al., 2009). EPS producing bacterial strains Planomicrobium chinense strain $\mathrm{P} 1$ and Bacillus cereus strain P2 effectively reduced the negative effects of drought stress by improving, sugar, chlorophyll and protein contents of wheat grown as a rainfed crop (Khan and Bano, 2019).

\section{Production of phytohormones}

Microorganisms are known to produce plant hormones viz., indole acetic acid (IAA), gibberlic acid (GA) and absicic acid (ABA) which help plants tolerate drought conditions. The IAA whenever present at low concentration enhances cell elongation and root growth (Vilchez et al., 2016). The ABA under drought situations prevented the loss of water by closure of stomata; it also increased the root growth and accumulation of solutes (Raschke, 2006). Several plant beneficial bacteria synthesized these plant hormones IAA (Kuan et al., 2016), GA (Bottini et al., 2004) and ABA (Vurukonda et al., 2016) and helped plant to tolerate drought stress (Glick, 1995; Marulanda et al., 2009). The Rhizobium phaseoli (MR-2) and Mesorhizobium ciceri (CR-30 and CR-39) by the synthesis of IAA improved drought tolerance of wheat by increasing the root length (Hussain et al., 2014). The Azospirillum brasilense increased drought tolerance level of pearl millet (Pennisetum glaucum L.) by enhancing the root length, lateral roots and root hairs (Tien et al., 1979). Inoculation of Pseudomonas spp. strain AKM-P6 improved the survival of sorghum (Sorghum bicolor L.) seedlings at elevated temperatures $\left(47-50^{\circ} \mathrm{C}\right.$ day $/ 30-33^{\circ} \mathrm{C}$ night) upto 15 days vis-à-vis 5 days of noninoculated plants. It also enhanced the proline, sugar and amino acids and other metabolites (Ali et al., 2009). The Phyllobacterium brassicacearum strain STM196 increased the drought tolerance of Arabidopsis thaliana by delaying the switch over of vegetative phase to reproductive phase and also by enhancing water use efficiency (Bresson et al., 2013). Consortia of Paenibacillus polymyxa strain DSM 36, $P$. polymyxa strain Loutit and Rhizobium tropici (CIAT 899) helped the common bean (Phaseolus vulgaris L.) plants to alleviate drought stress by increasing the ABA concentration in shoots (Marcia et al., 2008). The Azospirillum lipoferum improved the drought stress tolerance in maize (Zea mays L.) plants through the synthesis of $\mathrm{ABA}$ and GA (Cohen et al., 2009).

\section{Enhancement of root growth}

Increasing the water uptake capacity of plants is very essential to overcome water stress (Long et al., 2008). Beneficial bacteria improved the water uptake of plants by increasing root length, lateral roots and root volume, so that, plants could take up water 
from deeper layers under stress conditions (Armada et al., 2014). Inoculation of maize (Zea mays L.) plants with endophytic bacteria viz., Burkholderia phytofirmans PsJN and Enterobacter sp. FD17 enhanced root growth, drought tolerance, plant biomass and yield (Naved et al., 2014b). The Bacillus thuringiensis AZP2 improved the drought tolerance of wheat (Triticum aestivum L.) plants by increasing the length and density of roots (Timmusk et al., 2014). Beneficial bacteria such as Azospirillum brasilense strain Az39 and Brayrhizobium japonicum strain E109 improved the germination of maize (Zea mays L.) and soybean (Glycine $\max$ L.) respectively (Cassan et al., 2009). Consortia of Pseudomonas striata, Azospirillum and Rhizobium helped in enhancing nodule number, nodule dry weight, plant height and dry matter of pigeon pea (Cajanus cajan L.) (Devanand et al., 2002). The combined application of Rhizobium tropici (CIAT 899) and Paenibacillus polymyxa (DSM 36) reduced the damages of drought and improved the nodulation, nitrogen content and plant growth in common bean (Phaseolus vulgaris L.) (Figueiredo et al., 2008). The Exophiala pisciphila helps sorghum plants to tolerate drought stress conditions upto one month by improving plant height, shoot dry weight (Zhang et al., 2016). Inoculation of sunflower with Bacillus pumilus SF3 increased root dry matter under water stress conditions (Forchetti et al., 2010). Seed treatment of pigeon pea (Cajanus cajan L.) with Enterobacter ludwigii SRI-229 improved the root weight of pigeon pea (Cajanus cajan L.) by $16 \%$ over untreated control (Gopalakrishnan et al., 2016). The Pseudomonas spp. strain OG caused enhancement of root length of green gram by $53 \%$ (Goswami et al., 2013). Two bacterial isolates Bacillus sp. (12D6) and Enterobacter sp. (16i) increased the drought tolerance of maize and wheat by improving root length, root branching and root surface area (Jochum et al., 2019). Sphingomonas sp. Cra20 by accelerating the development of lateral roots and root hairs improved the drought tolerance of Arabidopsis thaliana (Luo et al., 2019).

\section{Regulation of gene expression}

Whenever plants experience stress conditions, they switch on /off certain genes for survival. Over expression of certain genes in plants under drought stress conditions enhanced the tolerance level and yield (Sakuma et al., 2006). Trehalose triggers the expression of genes which encodes for stress tolerance, carbon and nitrogen metabolism in plants. Beneficial bacteria like Rhizobium etli causes over expression of trehalose-6-phosphate synthase gene (ReOtsA) in common bean (Phaseolus vulgaris L.) resulting in increased number of nodules, nitrogenase activity and crop biomass as compared to wild type $R$. etli (Suarez et al., 2008). Inoculation of green gram (Vigna radiata L.) with Pseudomonas aeruginosa GGRJ21 results in increased tolerance to drought by elevated expression of drought responsive genes viz., dehydrin (DHN), catalase (CAT1) and dehydration responsive element binding protein (DREB2A) (Sarma and Saikia, 2014). Treatment of wheat cv. Sids1 with Bacillus amyloliquefaciens 5113 and Azospirillum brasilense NO40, led to over expression of drought responsive genes i.e., ascorbate peroxidase (APXI) of ascorbate-glutathione redox cycle (Kasim et al., 2013). Real time PCR analysis of expression of dehydrin (drought responsive gene) in maize (Zea mays L.) showed that, the endophytes Bacillus licheniformis CRIDA MSEB 17, Bacillus subtilis CRIDA MSEB 78 and Bacillus subtilis CRIDA MSEB 72 enhanced the expression of dehydrin upto $30.51 \%, 33.56$ $\%$ and $40.32 \%$ respectively in terms of relative quantification of the gene in relation to control, revealing that bacterial endophytes modify the response of host plant to drought 
conditions (ICAR-CRIDA, 2017). The Paenibacillus polymyxa induced the expression of early response to dehydration (ERD 15), a drought responsive gene in Arabidopsis thaliana under drought stress conditions (Timmusk and Wagener, 1999). The Bacillus subtilis strain B26 protected the plants from moisture stress by upregulating the drought responsive genes such as DHN3like, LEA-14-A-like and DREB2B-like genes in Brachypodium distachyon (Gagné-Bourque et al., 2015).

\section{Manipulation of microbiome}

Microbiomes represents extremely complex group of organisms (Rascovan et al., 2016). Thorough knowledge of crop specific microbiome would help to modulate the microbiome in a way that would lead to better the growth and development of crop plants (De-la-Pena et al., 2014; Laksmanan et al., 2014; Rascovan et al., 2016; Tkacz Poole et al., 2015). Study of plant microbiome has been limited so far due to technical hiccups. With the advancement of high-throughput sequencing technologies like metagenomic analysis, large amount of information is available on the composition of microbial communities in the rhizosphere of different plants (Rascovan et al., 2016) like rice (Edwards et al., 2015), wheat (Donn et al., 2015), maize (Aira et al., 2010) and soybean (Mendes et al., 2014). The composition of microbiome varies with crop, soil type and prevailing environmental conditions, for example Proteobacteria, Bacteroidetes and Actinobacteria were predominant and Chloroflexi and Firmicutes were absent in the barley (Hordeum vulgare L.) root microbiome (Burgarelli et al., 2015). However, still a very little information is available on the effect of different abiotic stresses on the root microbiome of crop plants (Blee et al., 2013; De-la-Pena et al., 2014; Tkacz Poole et al., 2015). Drought considerably changes the composition of bacterial and fungal communities indicating that, this restructured microbiome might help the plant survival under adverse environmental situations (Santos-Medellin et al., 2017). In case of rice, water stressed plants had the dominance of Chlroflexi and actinobacteria with severe reduction of delta-proteobacteria and acidobacteria in comparison with the well watered plants (Santos-Medellin et al., 2017). Further research is required for the crop specific analysis of microbiome, since this would help to understand, explore and augment the level of drought responsive microorganisms in the overall composition of microbiome through external application. This enhanced level of drought responsive microorganisms would improve the adaptiveness of crop plants to water stress (Santos-Medellin et al., 2017). The main challenge here was to select appropriate microbial species or their consortia to deal with the situation (Gopal and Gupta, 2016).

\section{Omic approaches for the management of drought}

Several important drought responsive genes coding for proteins which protect the plants from abiotic stresses have been identified and characterized in different crops through functional genomics studies like transcriptomics, proteomics and metabolomics (Joshi et al., 2016). Extensive studies on functional genomics of drought tolerance have been done on Arabidopsis thaliana (Yin et al., 2014). However, functional genomics studies involving microorganisms and plants are mostly being done on salt stress (de Lorenzo et al., 2009; Kapardar et al., 2010; Zhao et al., 2009), cold stress (Liljeqvist et al., 2015) heavy metals and drought stress on crops like cucumber $(\mathrm{Li}$ et al., 2014), tomato (Zhang et al., 2011). These omic appraoaches have been discussed in a review by Meena et al., (2017). These 
kinds of studies in rainfed crops, involving microorganisms for drought tolerance are limited. Hence, in future, extensive functional genomics studies are required to understand the mechanisms and to enhance greater drought tolerance in dryland crops.

\section{Metabolic modelling for mitigating drought in rainfed crops}

Plant metabolism is a source of various useful metabolites for pharmaceutical and biotechnological applications (Baghalian et al., 2014). Metabolic engineering is a mechanism which involves the manipulation of metabolic pathways through regulation of gene expression (Jarboe et al., 2010). Plants differ in synthesis and accumulation of biochemical compounds to cope up with moisture stress conditions, for example legumes exhibit high tolerance to drought (Ashraf and Iram, 2005; Ford, 1984). Plant associated microorganisms also regulate the synthesis, accumulation and composition of various metabolites in plants under stress conditions (Rasmussen et al., 2012). Inoculation of Bacillus subtilis strain B26 to timothy (Phleum pratense L.) alters the plant metabolism under drought stress conditions leading to enhanced synthesis of sugars (sucrose and fructans) and amino acids (glutamic acid, asparagine) in roots and shoots when compared with non-inoculated plants (Gagne-Bourque et al., 2016). By delineating the profile of various metabolites in drought tolerant and susceptible crop plants would help to know the biochemical pathways affected by water stress and subsequently in developing highly tolerant crop plants (Silvente et al., 2012). Metabolic modelling helps to foresee and regulate plant metabolism to get desired outcome (Baghalian et al., 2014; Stitt et al., 2010). This can be achieved by inducing the accumulation of metabolites through regulation of gene expression.
Microorganisms also regulate the gene expression and synthesis of biochemical compounds in plants, which has been discussed in previous sections. Some of the available metabolic models include; AraCyc, a biochemical pathway database for Arabidopsis (Mueller et al., 2003) and MoTo DB, for tomato (Grennan 2009).

\section{Future Prospects}

Plants and microorganisms have long history of co-evolution (Backer et al., 2018). From the aforementioned literature it is evident that, beneficial bacteria through different mechanisms help to enhance the drought tolerance of plants under water deficit conditions. The available literature indicates that, most of studies using drought tolerant microorganisms have done in maize and wheat. There is a necessity to explore and exploit the effectiveness of these beneficial microbes in other cereals, legumes and millets as well. Moreover, rainfed production systems have not been systematically explored to identify native drought tolerant bacteria to enhance drought tolerance of rainfed crops (Saleem et al., 2018). It is true that, maize and wheat are the major staple food crops of the world after rice. The expected demand of these crops is around 3.3 billion tones by 2050 (FAO, 2016). This demand has to be met by overcoming catastrophic effects of climate change on agriculture such as loss of available arable land due to soil erosion, rise in sea level and with diminishing water resources. Moreover, cereal yields are stagnated all over the world (FAO, 2016). Under these circumstances, drought tolerant microorganisms provide an excellent option to improve the drought tolerance as well as of growth and yield of plants. Apart from improving soil health and crop productivity, biofertilizers and biopesticides also contribute to reducing the green house gas emissions into the atmosphere by helping in 
downscaling the use of agrochemicals, this inturn lead to minimizing the use of fossil fuels in the manufacture of agrochemicals (Havukainen et al., 2018). At present, most of these studies are confined to laboratory or research farms.

To enhance the outreach of these simple, low cost and eco-friendly technologies, more and more on-farm studies with active participation of farmers are required. With regard to consistency problem, identification of location specific microorganisms may help to overcome this. Since the microorganisms are well adapted to the prevailing conditions at their natural habitat such as $\mathrm{pH}$, nutrients, soil moisture and other native organisms. Besides this, there is also need to develop formulations of consortia having several plant growth-promoting characteristics and standard utilization procedures of the same to improve drought tolerance of plants.

Enormous potential exist in this kind of technology and could be one of the important approaches to sustain agricultural production in less developed and developing countries (Barea, 2015; Zoppellari et al., 2014). We need to integrate microbial technologies along with the agrochemicals in reduced quantities to sustain soil health and agricultural production (Ahmad et al., 2018).

In conclusions the development and implementation of novel innovative technologies are necessary to address the problem of drought in rainfed areas. Plant beneficial microorganisms can provide low cost, environment friendly drought mitigation solutions for improving the crop productivity. Manipulation of microbiome with crop specific useful microorganisms would help to improve growth, health and productivity of crop plants. In future, exhaustive studies are required to understand the effect of abiotic stresses vis-à-vis normal conditions on the composition of microbiome of rainfed cereals and legumes. This would help to manipulate the composition of microbiome, for example exploitation of drought tolerant microorganisms to get desired benefits in respect of crop growth and production. Metabolic modelling of rainfed crops under the influence of abiotic stress and microorganisms is also important, as this would helps to foresee and regulate plant metabolism to get expected outcome. Studies involving omic approaches and highthroughput phenotyping of plants under the influence of beneficial microorganisms under drought stress conditions are necessary to understand the mechanisms and to impart greater drought tolerance in dryland crops. In addition to water scarcity, drylands are also nutrient hungry with host of other problems. To address this issue in a comprehensive manner, a consortia of microorganisms with multiple functions such as nitrogen fixation, drought tolerance, nutrient solubilization and disease control is required to bring the multiple benefits under single umbrella. It would lead to greater acceptance and usage among the farmers. Further exploration of novel and efficient microorganisms with multiple benefits is necessary to sustain rainfed agricultural production. With the renewed push for organic agriculture, beneficial microorganisms being important component would play greater role in sustaining soil health, environment and agricultural production.

\section{Acknowledgements}

The authors are thankful to the Director, ICAR-Central Research Institute for Dryland Agriculture, Hyderabad for providing necessary facilities for undertaking this study.

Conflict of interest: The authors declare no conflict of interest. 


\section{References}

Abeles, F.B., Morgan P.W., and Saltvei, Jr M.E., 1992. Ethylene in plant biology $\left(2^{\text {nd }}\right.$ Edn.) Academic Press, San Diego.

Ahmad, M., Pataczek, L., Hilger, T.H., Zahir, Z.A., Hussain, A., Rasche, F., Schafleitner, R and Solberg, S.O., 2018. Perspectives of microbial inoculation for sustainable development and environmental management. Frontiers in Microbiology 9, 2992.

Aira, M., Gomez-BrandoAn, M., Lazcano, C., Baath, E., and Dom- Anguez, J., 2010. Plant genotype strongly modifies the structure and growth of maize rhizosphere microbial communities. Soil Biology and Biochemistry 42(12), 2276-2281.

Alami, Y., Achouak, W., Marol, C and Heulin, T., 2000. Rhizosphere soil aggregation and plant growth promotion of sunflowers by an exopolysaccharides-producing Rhizobium sp. strain isolated from sunflower roots. Applied and Environmental Microbiology 66-33933398.

Ali, S.K, Z., Sandhya, V., Grover, M., Kishore, N., Rao,L.V., and Venkateshwarulu, B. 2009. Pseudomonas sp. strain AKM-P6 enhances tolerance of sorghum seedlings to elevated temperatures. Biology and Fertility of Soils 46, 45-55.

Armada, E., Roldan, A., and Azcon, R. 2014. Differential activity of autochthonous bacteria in controlling drought stress in native Lavandula and Salvia plants species under drought conditions in natural arid soil. Microbial Ecology 67, 410-420.

Ashraf, M., and Iram, A. 2005. Drought stress induced changes in some organic substances in nodules and other plant parts of two potential legumes differing in salt tolerance. Flora 200, 535-546.

Backer, R., Rokem, J.S., Ilangumaran, G., Lamont, J., Praslickova, D., Ricci, E., Subramanian, S., and Smith, D.L. 2018. Plant growth-promoting rhizobacteria context, mechanisms of action, and roadmap to commercialization of biostimulants for sustainable agriculture. Frontiers in Plant Science 9, 1473.

Baghalian, K.M.H., and Schreiber, F. 2014. Plant Metabolic Modelling, Achieving New Insight into Metabolism and Metabolic Engineering. The Plant Cell 26, 3847-3866.

Bangash, N., Khalid, A., Mahmood, T., and Siddique, M.T. 2013. Screening rhizobacteria containing acc-deaminase for growth promotion of wheat under water stress. Pakistan Journal of Botany 45(SI), 91-96.
Barea, J.M. 2015. Future challenges and perspectives for applying microbial biotechnology in sustainable agriculture based on a better understanding of plant-microbiome interactions. Journal of Soil Science and Plant Nutrition 15, 261-282.

Bashan, Y., and Holguin, G. 1997. Azospirillum- plant relationships, environmental and physiological advances 1990 -1996. Canadian Journal of Microbiology 43, $03-121$

Blee, K., Hein, J., and Wolfe, G.V. 2013. Arabidopsis thaliana, A useful but limited model to investigate stress impacts on rhizosphere community composition and function. In: Bruijn, F.J. (Edn,). Molecular microbial ecology of the rhizosphere. Wiley, New York, p.p. $265-270$.

Blum, A. 2005. Drought resistance, water-use efficiency, and yield potential - are they compatible, dissonant, or mutually exclusive? Australian Journal of Agricultural Research 56(11), 1159-1168.

Bottini, R., Cassan, F., and Piccoli, P. 2004. Gibberellin production by bacteria and its involvement in plant growth promotion and yield increase. Applied Microbiology and Biotechnology 65, 497-503.

Bresson, J., Varoquaux, F., Bontpart, T., Touraine, B., and Vile, D. 2013. The PGPR strain Phyllobacterium brassicacearum STM196 induces a reproductive delay and physiological changes that result in improved drought tolerance in Arabidopsis. New Phytologist 200, $558-569$.

Budak, H., Hussain, B., Khan, Z., Ozturk, N.Z., and Ullah, N.2015. From genetics to functional genomics, Improvement in drought signaling and tolerance in wheat. Frontiers in Plant Science 6, 1012

Bulgarelli, D., Garrido-Oter, R., MuÈnch, P.C., Weiman, A., Droege, J., Pan, Y., M.c.Hardy, A., and Schulzelefert, P. 2015. Structure and function of the bacterial root microbiota in wild and domesticated barley. Cell Host and Microbe 17(3), 392-403.

Cassan, F., Perrig, D., Sgroy, V., Masciarelli, O., Penna, C., and Luna, V. 2009. Azospirillum brasilense Az39 and Bradyrhizobium japonicum E109, inoculated singly or in combination, promote seed germination and early seedling growth in corn (Zea mays L.,) and soybean (Glycine max L.,). European Journal of Soil Biology 45 (1), 28-35.

Chakraborty, U., Chakraborty, B.N., Chakraborty, A.P., and Dey, P.L. 2013. Water stress amelioration and plant growth promotion in 
wheat plants by osmotic stress tolerant bacteria. World Journal of Microbiology and Biotechnology 29, 789-803.

Chanway, C.P., and Holl, F.B. 1994. Growth of out planted lode pole pine seedlings one year after inoculation with plant growth promoting rhizobacteria. Forest Science 40, 238-246.

Chen, D., Wang, S., Cao, B., Cao, D., Leng, G., Li Hi, Yin, L., Shan, L., and Deng, X. 2016. Genotypic variation in growth and physiological response to drought stress and rewatering reveals the critical role of recovery in drought adaptation in maize seedlings. Frontiers in Plant Science 12 (6), 1241.

Chenu, C., and Roberson, E.B. 1996. Diffusion of glucose in microbial extracellular polysaccharide as affected by water potential. Soil Biology and Biochemistry 28, 877-884.

Chmielewska, K., Rodziewicz, P., Swarcewicz, B., Sawikowska, A., Krajewski, P., Marczak, L. et.al. 2016. Analysis of drought-induced proteomic and metabolomic changes in barley (Hordeum vulgare L.) leaves and roots unravels some aspects of biochemical mechanisms involved in drought tolerance. Frontiers in Plant Science 7, 1108.

Cohen, A.C., Travaglia, C.N., Bottini, R., and Piccoli, P. 2009. Participation of abscisic acid and gibberellins produced by endophytic Azospirillum in the alleviation of drought effects in maize. Botany 87- 455-462.

Comas, L.H., Becker, S.R., Mark, V.V., Cruz, Byrne, P.F., and Dierig, D.A. 2013. Root traits contributing to plant productivity under drought. Frontiers in Plant Science 4, 442.

Compant, S., Duffy, B., Nowak, J., Clément, C., and Barka, E.A. 2005. Use of plant growthpromoting bacteria for biocontrol of plant diseases: principles, mechanisms of action, and future prospects. Applied and Environmental Microbiology 71, 4951-4959.

Costerton, J.W., Cheng, K.J., Geesey, G.G., Ladd, T.I., and Nicke,1 J.C. 1987. Dasgupta M. and Marri T.J., Bacterial biofilms in nature and disease. Annual Reviews in Microbiology 41, 435- 464.

Creswell, R., and Martin, F.W. 1998. Dryland farming: crops and techniques for arid region. Educational Concerns for Hunger Organization (ECHO), Technical Note, North Fort Meyers FL, USA, 23.

Daryanto, S., Wang, L., and Jacinthe, P.A. 2016. Global Synthesis of drought effects on maize and wheat production. PLoS One 11(5), 9(eBook)0156362.

de Lorenzo, L., Merchan, F., Laporte, P., Thompson, R., Clarke, J., Sousa, C., and Crespi, M. 2009.
A novel plant leucine-rich repeat receptor kinase regulates the response of Medicago truncatula roots to salt stress. Plant and Cell $21,668-680$.

de Souza, R.S.C., Okura, V.K., Armanhi, J.S.L., Jorrín, B., Lozano, N., da Silva, M.J., GonzalezGuerrero, M., de Araujo, L.M., Verza, N.C., Bagheri, H. C., Imperial, J., and Arruda. 2016. Unlocking the bacterial and fungal communities' assemblages of sugarcane microbiome. Scientific Reports 6, 28774.

De-la-Peña, C., and Loyola-Vargas, V. M. 2014. Biotic Interactions in the Rhizosphere, A Diverse Cooperative Enterprise for Plant Productivity. Plant Physiology 166, 701-719.

Donn, S., Kirkegaard, J.A., Perera, G., Richardson, A. E., and Watt, M. 2015. Evolution of bacterial communities in the wheat crop rhizosphere. Environmental Microbiology 17(3), 610-621.

Edwards, J., Johnson, C., Santos-Medellô Ân, C., Lurie, E., Podishetty, N.K., Bhatnagar, S., Eisen, J.A., and Sundaresan, V. 2015. Structure variation, and assembly of the root-associated microbiomes of rice. Proceedings of National Academy of Science.112 (8), E911-E920.

Fang, Y., and Lizhong, X. 2016. General mechanisms of drought response and their application in drought resistance improvement in plants. Cellular and Molecular Life Sciences 72, 673689.

F.A.O., Save and Grow in practice: maize, rice, wheat. A guide to sustainable cereal production ISBN 978-92-5-108519-6. 2016. http://www.fao.org/3/a-i4009e.pdf.

Farooq, M., Gogoi, N., Barthakur, S., Baroowa, B., Bharadwa,j, N., Alghamdi, S.S., and Siddique, K.H.M. 2017. Drought stress in grain legumes during reproduction and grain filling. Journal of Agronomy and Crop Science 201, 81-102.

Farooq, M., Basra, S.M.A., Wahid, A., Cheema, Z.A., Cheema, M.A., and Khaliq, A. 2008. Physiological role of exogenously applied glycine-betaine in improving drought tolerance of fine grain aromatic rice (Oryza sativa L.). Journal of Agronomy and Crop Science 194, 325-333.

Figueiredo, M.V., Burity, H.A., Martínez, C.R., and Chanway, C.P. 2008. Alleviation of drought stress in the common bean (Phaseolus vulgaris L.) by co-inoculation with Paenibacillus polymyxa and Rhizobium tropici. Applied Soil Ecology 40,182-188.

Forchetti, G., Masciarelli, O., Izaguirre, M.J., Alemano, S., Daniel, Alvarez, D., and Abdala, G. 2010. Endophytic bacteria improve seedling growth of sunflower under water stress, 
produce salicylic acid, and inhibit growth of pathogenic fungi. Current Microbiology 61, 485-493.

Ford, C.W. 1984. Accumulation of low molecular weight solutes in water stressed tropical legumes. Phytochemistry 23 (5), 1007-1015.

Gagné-Bourque, F., Maye, B.F., Charron, J.B., Vali, H., Bertrand, A., and Jabaji, S. 2015. Accelerated growth rate and increased drought stress resilience of the model grass Brachypodium distachyon colonized by Bacillus subtilis B26. PLoS One 10(6), e0130456.

Gagné-Bourque, F., Annick, B., Annie, C., Konstantinos, A. A., and Suha, J. 2016. Alleviation of drought stress and metabolic changes in Timothy (Phleum pratense L.) Colonized with Bacillus subtilis B26. Frontiers in Plant Science 7, 584.

Gamalero, E., and Glick, B.R. 2015. Bacterial modulation of plant ethylene levels. Plant Physiology 169- 13-22.

Glick, B.R. 1995. The enhancement of plant growth by free -living bacteria. Canadian Journal of Microbiology 41, 109-11.

Glick, B.R. 2005. Modulation of plant ethylene levels by the bacterial enzyme ACC deaminase. FEMS Microbiology Letters 251(1), 1-7.

Glick, B.R. 2012. Plant growth-promoting bacteria: mechanisms and applications. Scientifica 1-15.

Glick, B.R. 2014. Bacteria with ACC deaminase can promote plant growth and help to feed the world. Microbiological Research 169(1), 30 39.

Gopa,1 M., and Gupta, A. 2016. Microbiome selection could spur next-generation plant breeding strategies. Frontiers in Microbiology 7, 1971.

Grennan, A.K. 2009. Mo To DB: A Metabolic Database for Tomato. Plant Physiology 151, 1701-1702.

Hameeda, B., Harini, G., Rupela, O., Wani, S., and Reddy, G. 2008. Growth promotion of maize by phosphate-solubilizing bacteria isolated from composts and macrofauna. Microbiological Research 163 (2), 234-242.

Hardoim, P.R., Van, O., Verbeek, L.S., Van, E., and lsas, J.D.2008 Properties of bacterial endophytes and their proposed role in plant growth. Trends in Microbiology16, 463-471.

Havukainen, J., Uusitalo, V., Koistinen, K., Liikanen, M., and Horttanainen, M. 2018. Carbon footprint evaluation of bio fertilizers, International Journal of Sustainable Development Planning 13(8), 1050-1060.

Hill, D.S., Stein, J.I., Torkewitz, N.R., Mors,e A.M., Howell, C.R., Pachlatko, J.P., Becker, J.O., and
Ligon, J.M, 1994. Cloning of genes involved in the synthesis of pyrrolnitrin from Pseudomonas fluorescens and role of pyrrolnitrin synthesis in biological control of plant disease. Applied and Environmental Microbiology 60, 78-85.

Hong, Z., Lakkineni, K., Zhang, Z., and Verma, D.P.S. 2000. Removal of feedback inhibition of 1 pyrroline-5-carboxylate synthetase results in increased proline accumulation and protection of plants from osmotic stress. Plant Physiology 122, 1129-1136.

Honma, M., and Shimomura, T. 1978. Metabolism of 1-aminocyclopropane-1-carboxylic acid. Agricultural Biology and Chemistry 42,18251831.

Hussain, M.B., Zahir, Z.A., Asghar, H.N., and Asghar, M. 2014. Exopolysaccharides producing rhizobia ameliorate drought stress in wheat. International Journal of Agriculture and Biology 16, 3-13.

ICAR-CRIDA 2017. Annual Report 2016-17, Central Research Institute for Dryland Agriculture, Hyderabad, India, 191.

Jarboe, L.R., Zhang, X., Wang, X., Moore, J.C., Shanmugam, K.T., and Ingram, L.O. 2010. Metabolic Engineering for Production of Biorenewable Fuels and Chemicals, Contributions of Synthetic Biology. Journal of Biomedicine and Biotechnology 1- 18.

Jha, Y., Subramanian, R.B., and Patel, S. 2011. Combination of endophytic and rhizospheric plant growth promoting rhizobacteria in Oryza sativa shows higher accumulation of osmoprotectant against saline stress. Acta Physiologiae Plantarum 33 (3), 797-802.

Jochum, M.D., Mc. Williams, Kl., Borrego, E.J., Kolomiets, M.V., Niu, G., Pierson, E.A., and Jo, Y.K. 2019. Bioprospecting pant growthpromoting rhizobacteria that mitigate drought stress in grasses. Frontiers in Microbiology 10, 2106

Joshi, R., Wani, S.H., Singh, B., Bohra, A., Dar, Z.A., Lone, A.A., Pareek, A., and Singla, Pareek., S.L.2016. Transcription factors and plants response to drought stress: Current understanding and future directions. Frontiers in Plant Science 7, 1029.

Juenger, T.E.2013. Natural variation and genetic constraints on drought tolerance. Current Opinion in Plant Biology 16, 274-281.

Kapardar, R.K., Ranjan, R., Grover, A., Puri, M., and Sharma, R. 2010. Identification and characterization of genes conferring salt tolerance to Escherichia coli from pond water metagenome. Bioresource Technology 101, 
3917-3924.

Karim, M.R., and Rahman, M.A. 2014. Drought risk management for increased cereal production in Asian least developed countries. Weather and Climate Extremes 7, 24-35.

Kasim, W.A., Osman, M.E., Oma,r M.N., Abd- ElDaim, I.A., Bejai, S., and Meijer, J. 2013. Control of drought stress in wheat using plant growth promoting bacteria. Journal of Plant Growth Regulation 32, 122-130.

Kasim, W.A., Gaafar, R.M., Abou-Ali, R.M., Omar, M.N., and Hewait, H.M. 2016. Effect of biofilm forming plant growth promoting rhizobacteria on salinity tolerance in barley. Annals of Agricultural Sciences 61 (2), 217 227.

Kavamura, V.N., Santos, S.N., da Silva, J.L., Parma, M.M., Ávila, L.A., Visconti, A., Zucchi, T.D., Taketani, R.G., Andreote, F.D., and de Melo, I.S. 2013. Screening of Brazilian cacti rhizobacteria for plant growth promotion under drought. Microbiological Research 168, 183 191.

Khan, N., and Bano, A. 2019. Exopolysaccharide producing rhizobacteria and their impact on growth and drought tolerance of wheat grown under rainfed conditions. PLoS One 14(9), (eBook)0222302.

Kiani, S.P., Talia,P., Maur, P., Grieu, P., Heinz, R., Perrault, A., Nishinakamusu, V., Hopp, E., Gentzbittel, L., Paniego, N., and Sarrafi., A. 2007. Genetic analysis of plant water status and osmotic adjustment in recombinant inbred lines of sunflower under two water treatments. Plant Science 172(4), 773-778.

Kloepper, J.W., and Schroth, M.N. 1978. Plant growthpromoting rhizobacteria on radishes. In: Ride M (Edn) Proceedings of the fourth International conference on plant pathogenic bacteria, $\left(2^{\text {nd }}\right.$ Edn.), Tours, Gibert-Clarey, France, pp. 879-882.

Kooyers, N.J. 2015. The evolution of drought escape and avoidance in natural herbaceous populations. Plant Science 234, 155-162.

Kuan, K.B., Othman, R., Rahim, A.K., and Shamsuddin, Z.H. 2016. Plant growthpromoting rhizobacteria inoculation to enhance vegetative growth, nitrogen fixation and nitrogen remobilisation of maize under greenhouse conditions. PLoS One 11(3), (eBook)0152478.

Laksmanan, V., Selvaraj, G., and Bais, H. 2014. Functional soil microbiome: belowground solutions to an aboveground problem. Plant Physiology166, 689-700.

Li Q, Zhao, P., Li J., Zhang, C., Wang, L., and Ren, Z.
2014. Genome wide analysis of the WD-repeat protein family in cucumber and Arabidopsis. Molecular Genetics and Genomics 289, 103124.

Liljeqvist, M., Ossandon, FJ., Gonzalez, C., Rajan, S., Stell, A., Valdes, J. et al., 2015. Metagenomic analysis reveals adaptations to a cold-adapted life style in a low-temperature acid mine drainage stream. FEMS Microbiology Ecology $91(4), 1-12$.

Lindow, S.E., and Brandl, M.T. 2003. Microbiology of the phyllosphere. Applied and Environmental Microbiology 69, 1875-1883.

Lobell, D.B., Schlenker, W., and Costa-Roberts., J. 2011. Climate trends and global crop production since 1980. Science 333(6042), 616-20.

Long. H.H., Schmidt, D.D., and Baldwin, I.T. 2008. Native bacterial endophytes promote host growth in a species-specific manner; phytohormone manipulations do not result in common growth responses. PLoS One 3, (eBook)2702.

Luo, L.J. 2010. Breeding for water-saving and droughtresistance rice (WDR) in China. Journal of Experimantal Botany 61(13), 3509-3517.

Luo, Y., Fang, w., Yaolong, H., Meng, Z., Jiangli, G., Taozhe, y., Hongmei, S., and Lizhe, A. 2019. Sphingomonas sp. Cra20 increases plant growth rate and alters rhizosphere microbial community structure of Arabidopsis thaliana under drought stress. Front Microbiol., 10, 1221.

Mafakheri, A., Siosemardeh, A., Bahramnejad, B., Struik, P.C., and Sohrabi, Y. 2010. Effect of drought stress on yield, proline and chlorophyll contents in three chickpea cultivars. Australian Journal of Crop Sciences 4, 580-585.

Maheswari, M., Varalaxmi, Y., Yadav, S.K., Jyothilakshmi, N., Vanaja, M., and Venkateswarlu, B. 2017. Enhanced tolerance of transgenic sorghum expressing mtlD gene to water-deficit stress. Indian Journal of Biotechnology 16, 63-67.

Mancosu, N., Snyder, R.L., Kyriakakis, G., and Spano, D. 2015. Water scarcity and future challenges for food production. Water 7(3), 975-92.

Mansour, M.M.F. 1998. Protection of plasma membrane of onion epidermal cells by glycine betaine and proline against $\mathrm{NaCl}$ stress. Plant Physiology and Biochemistry 36, 767-772.

Mantelin, S., and Touraine, B. 2004. Plant growthpromoting bacteria and nitrate availability: Impacts on root development and nitrate uptake. Journal of Experimental Botany 5527-34. 
Marasco, R., Rolli, E., Ettoumi, B., Vigani, G., Mapelli, F., Borin, S., Abou-Hadid, A.F., ElBehairy, U., Sorlini, C., Cherif, A., Zocchi, G., and Daffonchio, D. 2012. A drought resistancepromoting microbiome is selected by root system under desert farming. PLoS One 7 (10), (eBook)48479.

Marasco, R., Rolli, E., Vigani, G., Borin, S., Sorlini, C., Ouzari, H., Zocchi, G., and Daffonchio, D. 2013. Are drought-resistance promoting bacteria cross-compatible with different plant models? Plant Signalling and Behaviour 8, (eBook)26741.

Marcia, V.B.F., Burity, H.A., Martı'nez, C.R., and Chanway, C.P. 2008. Alleviation of drought stress in the common bean (Phaseolus vulgaris L.) by co-inoculation with Paenibacillus polymyxa and Rhizobium tropici. Applied Soil Ecology 40(1), 182-188.

Marulanda, A., Jose'-Miguel, B., and Azcon, R. 2009. Stimulation of plant growth and drought tolerance by native microorganisms (AM fungi and bacteria) from dry environments, mechanisms related to bacterial effectiveness. Journal of Plant Growth Regulation 28, 115124.

Mayak, S., Tirosh, T., and Glick, B.R. 2004. Plant growth-promoting bacteria that confer resistance to water stress in tomatoes and peppers. Plant Science 166 (2), 525-530.

Meena, K.K., Sorty, A.M., Bitla, U.M., Choudhary, K., Gupta, P., Pareek, A., Singh, D.P., Prabha, R., Sahu, P.K., Gupta, V.K., Singh, H.B., Krishanani, K.K., and Minhas, P.S. 2017. Abiotic stress responses and microbe-mediated mitigation in plants, The omics strategies. Frontiers in Plant Science 8- 172.

Mendes, L.W., Kuramae, E.E., Navarrete, A.A., van, Veen, J.A., and Tsai, S.M. 2014. Taxonomical and functional microbial community selection in soybean rhizosphere. The ISME Journal 8(8), 1577-1587.

Mirza, M.S., Ahmad, W., Latif, F., Haurat, J., Bally, R., Normand, P., and Kauser, A.M. 2001. Isolation, partial characterization and the effect of plant growth and the effect of plant growthpromoting bacteria (PGPB) on micropropagated sugarcane in vitro. Plant and Soil 237 (1), 47-54.

Mueller, L.A., Zhang, P., and Rhe, S.Y. 2003. AraCyc, A Biochemical Pathway database for Arabidopsis. Plant Physiology 132, 453-460.

Naseem, H., and Bano, A. 2014. Role of plant growthpromoting rhizobacteria and their exopolysaccharide in drought tolerance of maize. Journal of Plant Interactions 9, 689-
701.

Naveed, M., Hussain, M.B., Zahir, Z.A., Mitter, B., and Sessitsch, A. 2014a. Drought stress amelioration in wheat through inoculation with Burkholderia phytofirmans strain PsJN. Plant Growth Regulation 73, 121-131.

Naved, M., Mitter, B., Reichenauer, T.G., Wieczorek, K., and Sessitsch, A. 2014b. Increased drought stress resilience of maize through endophytic colonization by Burkholderia phytofirmans PsJN and Enterobacter sp. FD17. Environment and Experimental Botany 97, 30-39.

Ngumbi, E., and Kloepper, J. 2016. Bacterial mediated drought tolerance current and future prospects. Applied Soil Ecology 105, 109-125.

Pandey, S., Fartyal, D., Agarwal, A., Shukla, T., James, D., Kaul, T., Negi, Y.K., Arora, S., and Reddy, M.K. 2017. Abiotic stress tolerance in plants: Myriad roles of ascorbate peroxidase. Frontiers in Plant Science 8- 581.

Panke-Buisse, K., Poole, A.C., Goodrich, J.K., Ley, R.E., and Kao-Kniffin, J. 2015. Selection on soil microbiomes reveals reproducible impacts on plant function. The ISME Journal 9, 980989.

Qurashi, A.W., and Sabri, A.N. 2012. Bacterial exopolysaccharide and biofilm formation stimulate chickpea growth and soil aggregation under salt stress. Brazilean Journal of Microbiology 1183-1191.

Raschke, T.M. 2006. Water structure and interactions with protein surfaces. Current Opinions in Structural Biology 16, 152-159.

Rascovan, N., Carbonetto, B., Perrig, D., DoÂaz, M., Canciani, W., Abalo, M., et. Al. 2016. Integrated analysis of root microbiomes of soybean and wheat from agricultural fields. Scientific Reports 6- 280-84.

Rasmussen, S.A.J., Parsons, and Christopher, S.J. 2012. Metabolomics of forage plants: A review. Annals of Botany 110- 1281-1290.

Redman, R.S., Kim, Y.O., Woodward, C.J.D.A., Greer, C., Espino, L., Doty, S.L., and Rodriguez, R.J. 2011. Increased fitness of rice plants to abiotic stress via habitat adapted symbiosis: A strategy for mitigating impacts of climate change. PLoS One 6-(eBook)14823.

Reid, A. 2011. Microbes helping to improve Crop Productivity. Microbe Magazine 6 (10), 435439.

Roberson, E.B., and Firestone, M.K. 1992. Relationship between desiccation and exopolysaccharide production in a soil Pseudomonas sp. Applied and Environmental Microbiology 58, 1284-1291.

Rout, M.E. 2014. The plant microbiome. Advances in 
Botanical Research 69, 279-309.

Ruzzi,. M., and Aroca, R. 2015. Plant growthpromoting rhizobacteria act as biostimulants in horticulture. Scientia Horticulturae 196, 124 134.

Saikia, J., Sarma, R.K., Dhandia, R., Yadav, A., Bharali, R., Gupta, V.K., and Saikia, R. 2018. Alleviation of drought stress in pulse crops with ACC deaminase producing rhizobacteria isolated from acidic soil of Northeast India. Scientific Reports 8- 3560.

Sakuma, Y., Maruyama, K., Osakabe, Y., Qin, F., Seki, M., and Shinozaki, K. 2006. Functional analysis of an Arabidopsis transcription factor, DREB2A, involved in drought-responsive gene expression. Plant and Cell 18-1292-1309.

Saleem, A.R., Brunetti, C., Khalid, A., Della, Rocca., G., Raio, A., Emiliani, G. et..al. 2018. Drought response of Mucuna pruriens (L.) DC. inoculated with ACC deaminase and IAA producing rhizobacteria. PLoS One 13(2), (eBook)0191218.

Sallam, A., Alqudah, M.A., Dawood, F.A.M., Baenziger, P.S., and Borner, A. 2019. Drought stress tolerance in wheat and barley: Advances in physiology, breeding and genetics research. International Journal of Molecular Science 20(13)- 3137(eBook).

Sandhya, V., Ali, S.K., Grover, M., Reddy, G., and Venkateswarlu, B. 2009. Alleviation of drought stress effects in sunflower seedlings by the exopolysaccharides producing Pseudomonas putida strain GAP-P45. Biology and Fertility of Soils 46, 17-26.

Sandhya, V., Ali, S.Z., Grover, M., Reddy, G., and Venkateswarlu, B. 2010. Effect of plant growth promoting Pseudomonas spp. on compatible solutes, antioxidant status and plant growth of maize under drought stress. Plant Growth Regulation 62, 21-30.

Santos-Medellín, C., Edwards, J., Liechty, Z., Nguyen, B., and Sundaresan, V. 2017. Drought stress results in a compartment-specific restructuring of the rice root-associated microbiomes. MBio 8-00764-17(eBook).

Saravanakumar, D., Kavino, M., Raguchander, T., Subbian, P., and Samiyappan, R. 2011. Plant growth promoting bacteria enhance water stress resistance in green gram plants. Acta Physiologiae Plantarum 33, 203-209.

Sarma, R., and Saikia, R. 2014. Alleviation of drought stress in mung bean by strain Pseudomonas aeruginosa GGRJ21. Plant and Soil 377, 111126.

Schulz, B., and Boyle, C. 2006. What are endophytes? In: Schulz, J.E., Boyle, C.J.C., and Sieber, T.N.
(Eds.), Microbial root endophytes. SpringerVerlag, Berlin, pp.1-13.

Shahzad, S., Arif, M., Riaz, M., Iqbal, Z., and Ashraf, M.2013. mPGPR with varied ACC-deaminase activity induced different growth and yield response in maize (Zea mays L.) under fertilized conditions. European Journal of Soil Biology 57, 27-34.

Silvente, S., Sobolev, A.P., and Lara, M. 2012. Metabolite adjustments in drought tolerant and sensitive soybean genotypes in response to water stress. PLoS One 7(6),38554(eBook).

Somers, E., Vanderleyden, J., and Srinivasan, M. 2004. Rhizosphere bacterial signaling, A love parade beneath our feet. Critical Reviews in Microbiology 30, 205-235.

Sridevi, M., and Mallaiah, K.V. 2009. Phosphate solubilization by Rhizobium strains. Indian Journal of Microbiology 49 (1), 98-102.

Stitt, M., Sulpice, R., and Keurentjes, J. 2010. Metabolic networks, how to identify key components in the regulation of metabolism and growth. Plant Physiology 152, 428-444.

Stromberger, M.E., Byrne, I.A.P., Canela, M.M., Elamari, A.A., Manter, D.K., and Weir, T. 2017. Genotype-specific enrichment of 1 aminocyclopropane- 1-carboxylic acid deaminase positive bacteria in winter wheat rhizospheres. Soil Science Society of America Journal 81, 796-805.

Suarez, R., Wong, A., Ramı'rez, M., Barraza, A., Orozco, M.C., Cevallos, M.A., Lara, M., Herna'ndez, G., and Iturriaga, G. 2008. Improvement of drought tolerance and grain yield in common bean by over expressing trehalose-6-phosphate synthase in rhizobia. Molecular Plant Microbe Interactions 21, 958966.

Tardieu, F. 2013. Plant response to environmental conditions: Assessing potential production, water demand and negative effects of water deficit. Frontiers in Physiology 4-17.

Timmusk, S., Abd El-Daim, I.A., Copolovici, L., Tanilas, T., Kannaste, A., et al., 2014. Drought-tolerance of wheat improved by rhizosphere bacteria from harsh environments: Enhanced biomass production and reduced emissions of stress volatiles. PLoS One 9(5), 96086(eBook).

Timmusk, S., and Wagner, E.G.H. 1999. The plantgrowth-promoting rhizobacterium Paenibacillus polymyxa induces changes in Arabidopsis thaliana gene expression: a possible connection between biotic and abiotic stress responses. Molecular Plant Microbe Interactions 12-951-959. 
Tkacz, A., and Poole, P. 2015. Role of root microbiota in plant productivity. J. Exptl. Bot, 66, 21672175.

Ullah, A., Sun, H., Yang, X., and Zhang, X. 2017. Drought coping strategies in cotton: increased crop per drop. Plant Biotechnology Journal 15, 271-284.

Vardharajula, S., Ali, S.Z., Grover, M., Reddy, G., and Venkateshwarulu, B. 2011. Drought-tolerant plant growth promoting Bacillus spp, effect on growth, osmolytes, and antioxidant status of maize under drought stress. Journal of Plant Interactions 6,1-14.

Vilchez, S., and Manzanera, M. 2011. Biotechnological uses of desiccation- tolerant microorganisms for the rhizoremediation of soils subjected to seasonal drought. Applied Microbiology and Biotechnology 91, 1297-1304.

Vurukonda, S.K.P., Sandhya, V., Shrivastava, M., and Ali, S.K.Z. 2016. Enhancement of drought stress tolerance in crops by plant growth promoting rhizobacteria. Microbiological Research 184- 13-24.

Yin, H., Chen, C.J., Yang, J., Weston, D.J., Chen, J., Muchero, W., Ye, N., Tschaplinski, T.J., Wullschleger, S.D., Cheng, Z., Tuskan, G.A., and Yang, X. 2014. Functional genomics of drought tolerance in bioenergy crops. Critical Reviews in Plant Science 33, 205-224.

Zafar-ul-Hye, M., Danish, S., Abbas, M., Ahmad, M., and Munir, T.M. 2019. ACC deaminase producing PGPR Bacillus amyloliquefaciens and Agrobacterium fabrum along with biochar improve wheat productivity under drought stress. Agronomy 9(7), 343

Zhang, Q., Minggui, G., Yuan, J., Ying, H., Zhang, H., Wang, Y., and Hou, X. 2016. Dark septate endophyte improves drought tolerance in sorghum. International Journal of Agriculture and Biology 19(1), 53-60.

Zhang, X., Ervin, E., Evanylo, G., Sheron, C., and Peo, C. 2005. Biosolids impact on tall fescue drought resistance. Journal of Residue Science and Technology 2, 173-180.

Zhang, X., Zou, Z., Gong, P., Zhang, J., Ziaf, K., Li, X., et al., 2011. Over-expression of microRNA169 confers enhanced drought tolerance to tomato. Biotechnology Letters 33, 403-409.

Zhao, M.G., Chen, L., Zhang, L.L., and Zhang, W. H. 2009. Nitric reductase dependent nitric oxide production is involved in cold acclimation and freezing tolerance in Arabidopsis. Plant Physiology 151, 755-767.

Zhou, C., Ma, Z., Zhu, L., Xiao, X., Xie, Y., Zhu, J., and Wang, J. 2016. Rhizobacterial strain Bacillus megaterium BOFC15 induces cellular polyamine changes that improve plant growth and drought resistance. International Journal of Molecular Science 17(6), 976.

Zoppellari, F., Malus, Eligio, Chitarra, Walter, Lovisolo, Claudio, Federico, Spanna, Bardi, and Laura. 2014. Improvement of drought tolerance in maize (Zea mays L.) by selected rhizospheric microorganisms. Italian Journal of Agrometeorology 1, 5-18.

\section{How to cite this article:}

Manjunath, M., S. K. Yadav, S. Desai and Maheswari, M. 2020. Perspectives of Plant Associated Microorganisms in Drought Management of Crops. Int.J.Curr.Microbiol.App.Sci. 9(11): 991-1006. doi: https://doi.org/10.20546/ijcmas.2020.911.118 